\title{
Boreal Forests and the Global Carbon Cycle
}

Kauppi, P.E.

American Association for the Advancement of Science

1989

Kauppi, P.E. 1989. Boreal Forests and the Global Carbon Cycle. Science 243: 1535-1536.

http://hdl.handle.net/1975/304

Downloaded from Helda, University of Helsinki institutional repository.

This is an electronic reprint of the original article.

This reprint may differ from the original in pagination and typographic detail.

Please cite the original version. 


\section{Letters}

\section{Vitamin C Papers}

In the article "AIDS paper raises red flag at $P N A S^{\text {" }}$ by William Booth (News \& Comment, 10 Feb., p. 733), there are the following sentences: "One of the most famous red flags was Linus Pauling's paper in 1972 on vitamin $\mathrm{C}$ and cancer. That paper, and a handful of others, have never made it into print in the academy's journal."

I point out first that the paper was by Ewan Cameron and me. It was soon published in the journal Oncology (1); when it became publicly known that the paper had been refused by the Proceedings of the National Academy of Sciences U.S.A., the editor of Oncology sent us a cable saying that although it was the practice of Oncology to referee papers, he was accepting it for publication without having seen it.

Moreover, PNAS later published two papers by us (2) dealing with the prolongation of survival times in terminal human cancer patients by use of daily supplements of vitamin $\mathrm{C}$.

Linus Pauline Linus Pauling Institute of Science and Medicine, Palo Alto, CA 94306

\section{REPERENCES}

1. E. Cameron and L. Pauling, Oncology 27, 181 (1973).

2. , Proc. Natl. Acad. Sci. U.S.A. 73, 3685 (1976); ibid. 75, 4538 (1978)

\section{Native Plants: Conservation Priorities}

I welcome Leslie Roberts' coverage (Research News, 16 Dec., p. 1508) of the Center for Plant Conservation and its consortium of botanical gardens and arboreta, but the descriptions of the highest risk species ("pretty," "brilliant yellow-orange flowers," "stunning pink flowers") should not lead one to the conclusion that aesthetic value is the prime consideration for setting priorities in conservation activities. One of the species mentioned in Roberts' article, Amsinckia grandiflora, was known only from a small area east of San Francisco Bay when it was first collected a little over a century ago; it is now apparently restricted to two small populations that fluctuate in size from year to year. Other species of Amsinckia are serious agricultural pests, not only in California, but in Australia and southern Africa. Comparative studies of the population biology of a rare species and of closely related weedy ones may provide insights, not only into the basis for rarity, but also into the basis for rampant weediness. These studies could provide a basis for working out a conservation strategy for the rare species as well as a means of controlling the pestiferous ones.

ROBERT ORNDUFF

Director, Botanical Garden, University of Califomia,

Centennial Drive, Berkeley, CA 94720

\section{Teaching Machines}

U.S. students will continue to "flunk math [and] science" (News \& Comment, 10 Feb., p. 729) as long as it is taught as it now is. In 1960, in Roanoke, Virginia, an 8thgrade class, using primitive teaching machines and a hastily prepared program, went through all of 9th-grade algebra in half a year. Tested the following year, their retention was above normal. I visited that program. When I entered the room with its director, Allen Calvin, not a single student looked up at us. When I commented on that extraordinary fact, Calvin gave me a better demonstration. He went up to the teacher's platform, jumped in the air, and came down with a loud bang. Not a student looked away from the materials on the teaching machines. That is "motivation," not from fascinating subject matters, but from the assurance of success.

Computers are now much better teaching machines (they are not computing when they teach), but the basic principles of programmed instruction are not yet being followed. Why not? Possibly because cognitive psychologists, claiming an esoteric knowledge of how students think, opposed them. Students were to think as mathematicians thought. The result, of course, was the New Math. That was the age-old strategy underlying all changes in curricula: when students are not learning, teach them something else. The failure of the New Math is now clear.

A good example of what happened to physics teaching after Sputnik is the work of Jerrold Zacharias, a distinguished physicist and a great teacher, who prepared fascinating instructional materials for classroom use. Later, he would blame the teachers for their failure. But it was the method of teaching, not the materials used, that needed to be improved.

Good instruction demands two things: students must be told immediately whether what they do is right or wrong and, when right, they must be directed to the step to be taken next. A tutor can do that with a student or two, but it is quite beyond the reach of the teacher with 20 or 30 students. The teaching profession must turn, as all other professions have turned, to instrumentation. That will not dehumanize teaching; it will free it from what is now essentially the inhumane punitive formula of "study and learn or else."

B. F. SKINNER

Department of Psychology,

Harvard University, Cambridge, MA 02138

\section{Boreal Forests and the Global Carbon Cycle}

Roger Sedjo's comment (Letters, 30 Sept., p. 1737) on the global carbon cycle refers to a study by the International Institute for Applied Systems Analysis (IIASA) which estimated that a global warming could increase the growth rate of northern boreal forests by 75 to $100 \%$. As Clark S. Binkley (Letters, 24 Feb., p. 991) notes, Sedjo's citation was incorrect; the result was part of the IIASA study, but was published in (1). Of more concern is that the result was taken out of its context and was misinterpreted as regards the global carbon cycle.

Our study (1) was similar to that of Emanuel et al. (2), who depicted future biomes (life zones) assuming a climatic warming. Their analysis covered all continents, whereas ours focused on boreal forests in the belt between 38 and 70 degrees northern latitude. Our main objective was to locate regions within the boreal zone where a possible climatic warming could induce strongest ecological reactions. We used two indicator variables, one of which was annual tree growth. Given a model scenario of greenhouse gas warming (3), the analysis suggested that ecosystems could respond more strongly in maritime parts of the boreal zone than in continental parts. The analysis was coarse and was based on simple ecological models. However, the results lend support to more detailed studies, especially in maritime parts of the zone.

Our results indicated that climatic warming could enhance tree growth in boreal forests. This should not be any surprise. Temperate forests grow faster than boreal forests because the growing conditions are more favorable. If boreal vegetation were to be replaced by temperate vegetation as Emanuel $e t$ al. suggest (2), tree growth in the long run would increase, although there would be a troublesome adaptation and migration period, as we discussed (1).

Sedjo proposed that the global warming that has been recorded during this century may have stimulated tree growth in boreal forests. That, he says, could have strengthened the terrestrial sink of armospheric carbon. This, according to Sedjo, could solve 
part of the "missing carbon problem" (4) and balance the global carbon budget for 1980.

Such issues should be studied in detail, but we do not think our study lends support to Sedjo's argument. In response to a climatic warming, the boreal zone can act as a source of carbon dioxide rather than as a sink. Soil organic carbon in active exchange with the atmosphere constitutes approximately two-thirds of the carbon in terrestrial ecosystems (5). Increased release of carbon from soil in response to climatic warming may more than compensate for the effect of growth stimulation.

Pekra KaupPI ${ }^{*}$ Finnish Acidification Research Project (HAPRO), Eteläesplanadi $18 \mathrm{~A}$, SF-00120 Helsinki, Finland Maximillan Posch* Austrian Research Center, A-2444 Seibersdorf, Austria

\section{REFERENCES}

1. P. Kauppi and M. Posch, in The Impaa of Climatic Variations on Agriculture, vol. 1, Assessments in Cool, Temperate and Cold Regions, M. L. Parry, T. R. Carter, N. T. Konijn, Eds. (Kluwer Academic, Norwell, MA, 1988), pp. 183-195.

2. W. R. Emanuel, H. H. Shugart, M. P. Stevenson, Clim. Change 7, 457 (1985).

3. W. Bach, in The Impad of Climatic Variations on
Agriculture, vol. 1, Assessments in Cool, Temperate and Cold Regions, M. L. Parry, T. R. Carter, N. T. Konijn, Eds. (Kluwer Academic, Norwell, MA, 1988), pp. 125-157.

4. R. P. Detwiler and C. A. S. Hall, Science 239, 42 (1988).

5. W. M. Post, W. R. Emanuel, P. J. Zinke, A. G. Stangenberger, Nature 298, 156 (1982).

*Formerly at the International Institute for Applied Systems Analysis (IIASA), A-2361 Laxenburg, Austria.

\section{La Différence}

Donald S. McLaren (Letters, 22 July 1988 , p. 399) contends that the sex difference in the relation between resting oxygen consumption and surface area that I have postulated to prevail (Letters, $8 \mathrm{Apr}$. 1988, p. 130) disappears when expressed in terms of lean body mass. McLaren's contention is supported by experiments "carried out by medical students on themselves" (1). However, extensive studies by others, particularly those of Novak (2), clearly show in 215 healthy men and 305 women that fat-free mass and cellular mass are significantly lower $(P<0.001)$ in women than in men at all adult age levels. Fat-free, that is, lean body mass, was determined with ${ }^{40} \mathrm{~K}$ gamma-ray spectrometry (fat does not contain potassi- um), and it was found that relative (fat-free) body cell mass is $18.5,13.4,17.21,19.4$, and $13.4 \%$ lower in women in the age brackets 18-25, 25-35, 35-45, 45-55, 5565 , and $65-85$ years, respectively. The data on the 18- to 25-year-old group, that is, the age group of the medical students (1) cited by McLaren, display a large standard deviation.

My contention that women live longer than men because of their more efficient use of energy is expressed in terms of resting oxygen consumption. That a constant proportion of the difference in longevity is based on the relation between body mass and energy expenditure is, however, also manifest in the differential response to performance on a variety of tasks, including standing, walking, household work, football, and mining. On all tasks men expend more energy than women (3). I reiterate, therefore: "Vive la Différence!"

ROLAND FISCHER 07190 Esporles, Mallorca, Spain

\section{REFERENCES}

1. M. G. MacMillan, C. M. Reid, M. Shirling, R. Passmore, Lancet i, 728 (1965).

2. L. P. Novak, J. Gerontol. 27, 438 (1972).

3. Wissenschaftliche Tabellen Geigy: Körperflüssigkeiten (Ciba-Geigy, Bascl, od. 8, 1981), p. 225. 